\title{
Geometric Structure and Electronic Polarization Synergistically Boost Hydrogen Evolution Kinetics in Alkaline Medium
}

Shanlin Li, Ruguang Ma, * Yu Pei, Baohua Mao, Hongliang Lu, Minghui Yang, Tiju Thomas, Danmin Liu, * and Jiacheng Wang*

*Address correspondence to maruguang@mail.sic.ac.cn (R.G. Ma), jiacheng.wang@mail.sic.ac.cn (J.C. Wang) and dmliu@bjut.edu.cn (D.M. Liu) 


\section{Experimental section \\ Materials}

Sliver nitrate $\left(\mathrm{AgNO}_{3}\right)$, ruthenium chloride hydrate $\left(\mathrm{RuCl}_{3} \cdot \mathrm{xH}_{2} \mathrm{O}\right)$, iron trichloride $\left(\mathrm{FeCl}_{3}\right)$, ethylene glycol, sodium borohydride $\left(\mathrm{NaBH}_{4}\right)$, acetone and ethanol are purchased from Sinopharm chemical reagent Co., Ltd in China. Polyvinyl-pyrrolidone (PVP) is purchased from Aladdin.

\section{Synthesis of Ag NWs}

Silver nanowires (NWs) are synthesized referring to the previous work: ethylene glycol $(120 \mathrm{~mL})$, sliver nitrate $(1.1 \mathrm{~g})$, polyvinyl-pyrrolidone (PVP) $(0.98 \mathrm{~g})$ and FeCl3aq. $(16 \mathrm{~g}, 600 \mu \mathrm{M})$ are mixed in a flask. Then the flask is placed in an oil bath pot at $160^{\circ} \mathrm{C}$ for $1 \mathrm{~h}$. The products are washed twice by utilizing acetone and ethanol respectively, and then dispersed in water. AgNWs are collected by freeze-drying for 24 h.

\section{Synthesis of Ru/AgCl@Ag}

In a typical preparation of the $\mathrm{Ru} / \mathrm{AgCl} @ \mathrm{Ag}, 10 \mathrm{mg} \mathrm{AgNW}$ s are dispersed in 10 $\mathrm{mL}$ of water. This is followed by the addition of $0.05,0.1,0.2$ or $0.3 \mathrm{~mL} \mathrm{RuCl} 3$ solution $(0.01 \mathrm{~g} \mathrm{~mL}-1)$. Then the mix solution is stirred continuously for $0.5 \mathrm{~h}$. Then aqueous solution of $\mathrm{NaBH} 4$ is introduced in a drop wise manner into the mix solution. This is done while vigorously stirring the mixture. After $1 \mathrm{~h}$, the product obtained, $\mathrm{Ru} / \mathrm{AgCl} @ \mathrm{Ag}-\mathrm{X} \%$ ( $\mathrm{X}$ is the proportion of $\mathrm{RuCl} 3$ to $\mathrm{Ag} \mathrm{NWs}, \mathrm{X}=5,10,20,30$ ), is centrifuged and washed with water and anhydrous ethanol for several times and dried at $60{ }^{\circ} \mathrm{C}$ for $8 \mathrm{~h}$. Intermediate products are synthesized with different GRR time: 0.5 and 24 hours. These samples are denoted as G-0.5 and G-24, respectively.

\section{Synthesis of Ru@Ag}

$\mathrm{Ru} @ \mathrm{Ag}$ as the control sample is fabricated through direct reduction by NaBH4. AgNWs are dispersed in water; $1 \mathrm{mg}$ of $\mathrm{NaBH} 4$ is then added into the AgNWs, which is then mixed with $0.1 \mathrm{~mL} \mathrm{RuCl} 3$ solution $(0.01 \mathrm{~g} \mathrm{~mL}-1)$. After $1 \mathrm{~h}$, the final product, $\mathrm{Ru} @ \mathrm{Ag}$, is centrifuged and washed using water and anhydrous ethanol several times and dried at $60{ }^{\circ} \mathrm{C}$ for $8 \mathrm{~h}$.

\section{Materials Characterization}

The microstructures are examined by using a field emission scanning electron microscope (SEM, FEI Magellan 400L XHR). Transmission electron microscope (TEM) images are taken on JEM-2100F. The EDS mapping is operated on a Titan G2 60-300 Cs-corrected TEM with accelerating voltage of $300 \mathrm{kV}$. X-ray diffraction (XRD) patterns of the samples are collected using a D8 ADVANCE X-ray diffractometer. X-ray photoelectron spectroscopy (XPS) measurements are conducted on a Thermo ESCALAB250xi electron spectrometer using Al Ka source (1486.6 eV) as the radiation source. The binding energy is referenced to the $\mathrm{C} 1 \mathrm{~s}$ peak at $284.8 \mathrm{eV}$, which comes from adventitious carbon. Fourier transform infrared spectroscopy (FTIR) spectra are collected using a Nicolet ls10 infrared spectrometer with a resolution of 4 $\mathrm{cm}-1$. All samples are mixed with $\mathrm{KBr}$ by grinding. There after the mix is pressed into tablets.

\section{AP-XPS Measurement}


The measurements are carried out using a customized, lab-based AP-XPS instrument (Specs Co.). The system is equipped with a monochromic Aluminum $\mathrm{K}_{\alpha}$ source and PHOIBOS 150 NAP analyser.

\section{Electrochemical Measurements}

Electrochemical measurements are performed on an electrochemical workstation (CHI760C, Shanghai Chenhua Instrument Co., China) by using a standard threeelectrode system in $1 \mathrm{M} \mathrm{KOH}$ electrolyte at room temperature. Prior to measurement, the catalysts are deposited on a glassy carbon electrode (GCE) as the working electrode. A graphite rod is used as the counter electrode, and a saturated calomel electrode (SCE) is used as the reference electrode. The working electrode is prepared as follows. $5 \mathrm{mg}$ of the as-prepared catalysts is dispersed in the mixed solution of $0.5 \mathrm{~mL}$ of distilled water, $0.5 \mathrm{~mL}$ of ethanol, and $20 \mu \mathrm{L}$ of Nafion solution. The suspension is sonicated for $1 \mathrm{~h}$ to get a homogeneous ink. Then, $20 \mu \mathrm{L}$ of catalyst ink is dropped onto a freshly polished GCE ( $5 \mathrm{~mm}$ diameter) and dried at $60{ }^{\circ} \mathrm{C}$ to obtain the working electrode. The areal loading mass of the working electrode is $0.51 \mathrm{mg} \mathrm{cm}^{-2}$. The working electrode is rotated at $1600 \mathrm{rpm}$ during the tests. All applied potentials are converted to reversible hydrogen electrode (RHE) using the following equation: $\mathrm{E}_{\mathrm{RHE}}(\mathrm{V})=\mathrm{E}_{S C E}+0.059 \times \mathrm{pH}$ +0.242 .

The catalysts are activated by linear sweep voltammetry (LSV) for tens of times. Polarization curves are obtained by LSV at a scan rate of $5 \mathrm{mV} \mathrm{s}^{-1}$. All polarization curves are $90 \%$ iR corrected. Tafel slopes are obtained by plotting overpotential $\eta$ against $\log (\mathrm{J})$ via LSV curves. Electrochemical impedance spectroscopy (EIS) is measured under a bias of $-1.25 \mathrm{~V} V s$. SCE in the frequency range of $1-10^{5} \mathrm{~Hz}$. The stability of catalysts is estimated using chronopotentiometry at $10 \mathrm{~mA} \mathrm{~cm}$.

Electrochemical active surface areas (ECSA) are determined using cyclic voltammetry in the potential window of $0.205-0.305 \mathrm{~V} \mathrm{Vs}$. RHE, at the scan rate of 20, $40,60,80,100$, and $120 \mathrm{mV} \mathrm{s}^{-1}$, respectively. The double-layer capacitance $\left(\mathrm{C}_{\mathrm{dl}}\right)$ is calculated by plotting the difference of current density $\left(\Delta \mathrm{J}=\mathrm{J}_{\mathrm{a}}-\mathrm{J}_{\mathrm{c}}\right)$ at $0.25 \mathrm{~V} \mathrm{Vs}$. RHE against the scan rate. A slope, twice that of $\mathrm{C}_{\mathrm{dl}}$ is used to represent ECSA. Linear fitting reveals that the specific capacitance is 2.7, 5.9, 24.4, 22.6 and $19.4 \mathrm{mF} \mathrm{cm}^{-2}$ for $\mathrm{Ru} / \mathrm{AgCl} @ \mathrm{AgNWs}-5 \%, \quad \mathrm{Ru} / \mathrm{AgCl} @ \mathrm{AgNWs}-10 \%, \quad \mathrm{Ru} / \mathrm{AgCl} @ \mathrm{AgNWs}-20 \%$, $\mathrm{Ru} / \mathrm{AgCl} @ \mathrm{AgNWs}-30 \%$ and $\mathrm{Pt} / \mathrm{C}$ catalysts in $1 \mathrm{M} \mathrm{KOH}$, assuming that the specific capacitance of a flat surface is $\sim 40 \mu \mathrm{F}$ for $1 \mathrm{~cm}^{2}$ of real surface area.

The ECSA is estimated as:

$$
A_{E C S A}^{S A M P L E}=\frac{\text { specific capacitance }}{40 u \mathrm{Fcm}^{-2} \text { per } c m_{E C S A}^{2}}
$$

Taking $\mathrm{Pt} / \mathrm{C}$ as an example upon the hydrogen evolution reaction, the AECSA of $\mathrm{Pt} / \mathrm{C}$ can be calculated as: 


\begin{tabular}{|c|c|c|}
\hline Sample & $C_{d l} / \mathrm{mF} \mathrm{cm}^{-2}$ & $A_{E C S A} / \mathrm{cm}_{E C S A}^{-2}$ \\
\hline Ru/AgCl@AgNWs-5\% & 2.7 & 67.5 \\
\hline Ru/AgCl@AgNWs-10\% & 5.9 & 147.5 \\
\hline Ru/AgCl@AgNWs-20\% & 24.4 & 610 \\
\hline Ru/AgCl@AgNWs-30\% & 22.6 & 565 \\
\hline $\mathrm{Pt} / \mathrm{C}$ & 19.4 & 485 \\
\hline
\end{tabular}

Mass activity of catalysts is studied by normalizing the polarization curves based on the loading of Ru and Pt.

Turnover frequency (TOF) is calculated using the following formula:

TOF

$$
\begin{aligned}
& =\left(j \frac{m A}{\mathrm{~cm}^{2}}\right)\left(\frac{1 \mathrm{C}^{-1}}{1000 \mathrm{~mA}}\right)\left(\frac{1 \mathrm{~mol} \mathrm{e}^{-1}}{96485 \mathrm{C}}\right)\left(\frac{1 \mathrm{~mol} \mathrm{H}}{2 \mathrm{~mol} \mathrm{H}^{-1}}\right)\left(\frac{6.02 \times 10^{23} \mathrm{H}_{2} \text { molecules }}{1 \mathrm{~mol} \mathrm{H_{2 }}}\right) \\
& =3.12 \times 10^{15} \frac{\mathrm{H}_{2} \mathrm{~S}^{-1}}{\mathrm{~cm}^{2}} \text { per } \frac{\mathrm{mA}}{\mathrm{cm}^{2}} \text { Equation } 1
\end{aligned}
$$

The number of active sites per real surface area for $\mathrm{Ru} / \mathrm{AgCl} @ \mathrm{Ag}$ and $\mathrm{Pt} / \mathrm{C}$ are obtained from the unit cell of $\mathrm{Ru}$ and Pt:

$\#$ active sites $\mathrm{Ru}=\left(\frac{2 \text { atoms } / \text { unitcell }}{2.702 \mathrm{~nm}^{3} / \text { unitcell }}\right)^{2 / 3}=1.76 \times 10^{15}$ atoms $\mathrm{cm}^{-2} \quad$ Equation 2 $\#$ active sites $\mathrm{Pt}=\left(\frac{4 \text { atoms } / \text { unitcell }}{6.038 \mathrm{~nm}^{3} / \text { unitcell }}\right)^{2 / 3}=1.64 \times 10^{15}$ atoms $\mathrm{cm}^{-2} \quad$ Equation 3 Therefore, the TOF value can be obtained from the following formula:

$\mathrm{TOF}=\frac{\left(3.12 \times 10^{15} \frac{\mathrm{H}_{2} \mathrm{~s}^{-1}}{\mathrm{~cm}^{2}} \mathrm{per} \frac{\mathrm{mA}}{\mathrm{cm}^{2}}\right) \times|j|}{\# \text { active sites } \times \mathrm{A}_{\mathrm{ECSA}}}$

Equation 4

Hydrogen production in cost (HPC) is calculated using the following procedures: ${ }^{[\mathrm{S} 1]}$ Firstly, the prices per electrode area $\left(0.196 \mathrm{~cm}^{2}\right)$ of the catalysts.

Price $_{\text {sample }}$ per $\mathrm{cm}^{2}=$ catalyst load $\times(\$ 61$ per oz $\times R u$ wt. $\%+\$ 17.2$ per oz $\times$ Agwt.\%)

Equation 5

Price $_{P t / C}$ per $\mathrm{cm}^{2}=$ catalyst load $\times \$ 960$ per oz $\times P t w t . \%$ Equation 6 The catalyst load per $\mathrm{cm}^{2}$ is $510 \mu \mathrm{g}$. And according to Equation 1, 
$\mathrm{HPC}_{\text {sample }}=3.12 \times 10^{15} \frac{\mathrm{H}_{2} S^{-1}}{\text { Price }_{\text {sample }} \times N_{A} \times V_{m}}$ per $\frac{\mathrm{mA}}{\mathrm{cm}^{2}}=\frac{1.16 \times 10^{-7}}{\text { Price }_{\text {sample }}} L^{-1}$ per $j$

Equation 7

For example, the HPC of $\mathrm{Ru} / \mathrm{AgCl} @ \mathrm{AgNWs}-20 \%$ in $1.0 \mathrm{M} \mathrm{KOH}$ is calculated as

Price $_{R u / A g C l @ A g N W s-20 \%}$ per cm ${ }^{2}$

$$
\begin{aligned}
& =510 \mu \mathrm{g} \times(\$ 61 \text { per oz } \times 16.7 w t . \%+\$ 17.2 \text { per oz } \times 83.3 w t . \%) \\
& =\$ 4.41 \times 10^{-4} \text { per } \mathrm{cm}^{2}
\end{aligned}
$$

Price $_{P t / C}$ per $\mathrm{cm}^{2}=510 \mu \mathrm{g} \times \$ 960$ per oz $\times 20 w t . \%=\$ 3.46 \times 10^{-3}$ per $\mathrm{cm}^{2}$

$$
\begin{gathered}
\mathrm{HPC}_{R u / A g C l @ A g N W s-20 \%}=\frac{1.16 \times 10^{-7}}{\text { Price }_{\text {sample }}} L s^{-1} \text { per } j=\frac{1.16 \times 10^{-7}}{\$ 4.41 \times 10^{-4}} L s^{-1} \text { per } j \\
=2.63 \times 10^{-4} L s^{-1} \text { per dollar per } j \\
\mathrm{HPC}_{P t / C}=\frac{1.16 \times 10^{-7}}{\$ 3.46 \times 10^{-3}} L s^{-1} \text { per } j=3.35 \times 10^{-5} L s^{-1} \text { per dollar per } j
\end{gathered}
$$

\section{Theoretical Simulation}

First-principle density function theory (DFT) calculations are performed by using Vienna Ab initio Simulation Package (VASP). The interaction between core and valence electrons is described using projector augmented wave (PAW) pseudopotentials. The cut-off energy of $400 \mathrm{eV}$ is used to expand the plane wave basis and the generalized gradient approximation (GGA) is used for the electron exchange correlations. The Brillouin zone integration is performed using the $\Gamma$ point due to the large system size and sampled using Monkhorst-Pack $3 \times 3 \times 1$ k-points. The thickness of the vacuum is $15 \AA$ in the $\mathrm{z}$ axis to avoid the interaction between nearby slabs. During the geometry optimization, the convergence criterion for force and energy is set to 0.02 $\mathrm{eV} / \AA$ and $1 \times 10^{-5} \mathrm{eV}$, respectively.

The free energy of hydrogen adsorption $\left(\Delta \mathrm{GH}^{*}\right)$ is calculated following the equations as follows:

$\Delta \mathrm{G}_{\mathrm{H}}=\Delta \mathrm{E}+0.24 \mathrm{eV}$

The free energy is calculated using the equation:

$\mathrm{G}=\Delta \mathrm{E}+\mathrm{ZPE}-\mathrm{TS}$

DFT based adsorption energy of $\mathrm{H}$ or water, ZPE and TS are the zero-point energy and entropic contributions $(\mathrm{T}=298 \mathrm{~K})$, respectively. $\Delta \mathrm{E}$ is the adsorption energy which is defined as follows:

$\Delta \mathrm{E}=\mathrm{E}_{\text {sub+ads }}-\mathrm{E}_{\text {sub-Eads }}$

\section{Reference:}

[S1]. Li, K.; Li, Y.; Wang, Y. M.; Ge, J. J.; Liu, C. P.; Xing, W. Enhanced electrocatalytic performance for the hydrogen evolution reaction through surface enrichment of platinum nanoclusters alloying with ruthenium in situ embedded in carbon. Energy Environ. Sci. 2018, 11, 1232-1239. 

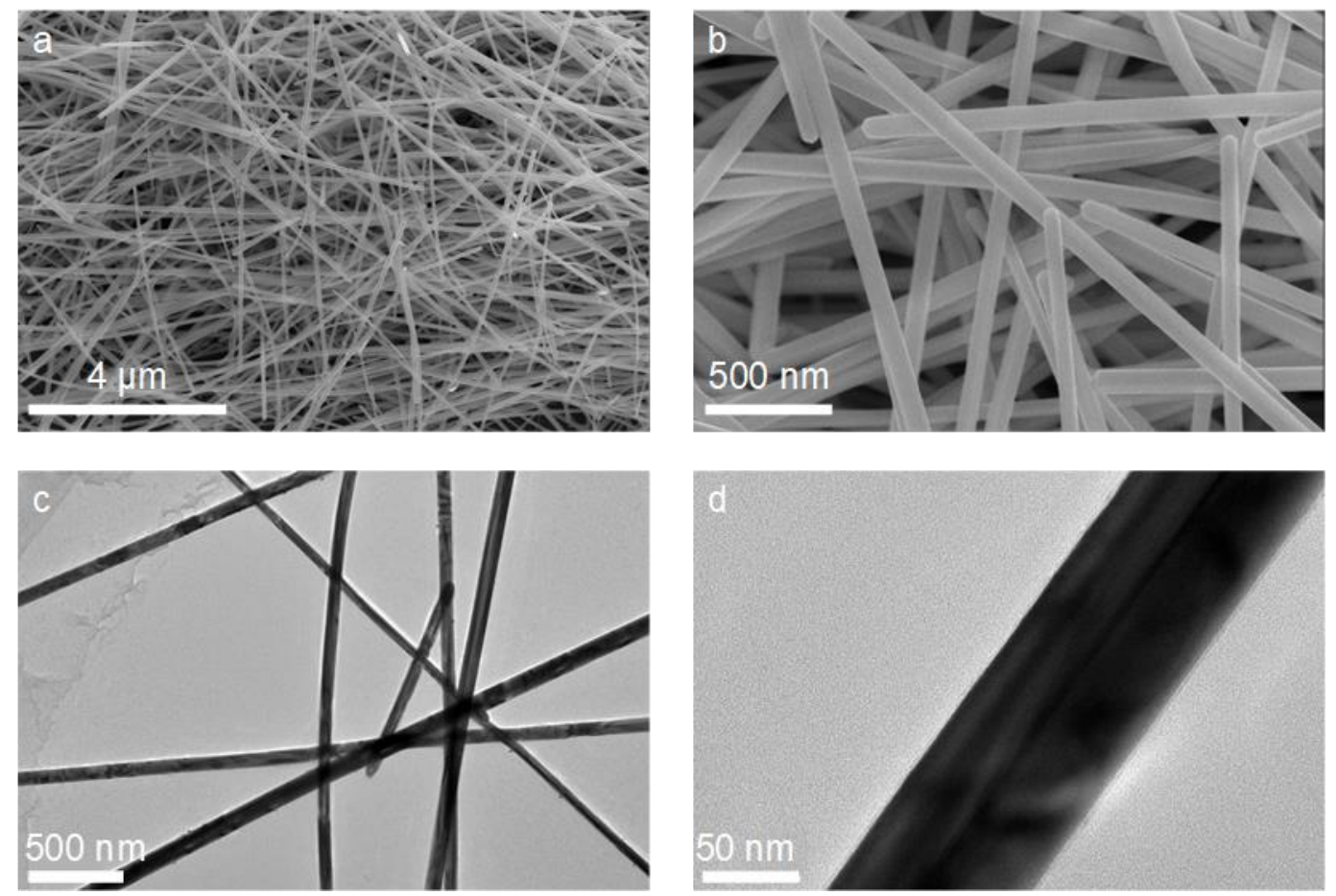

Fig. S1 Typical SEM (a-b) and TEM (c-d) images of AgNWs. 

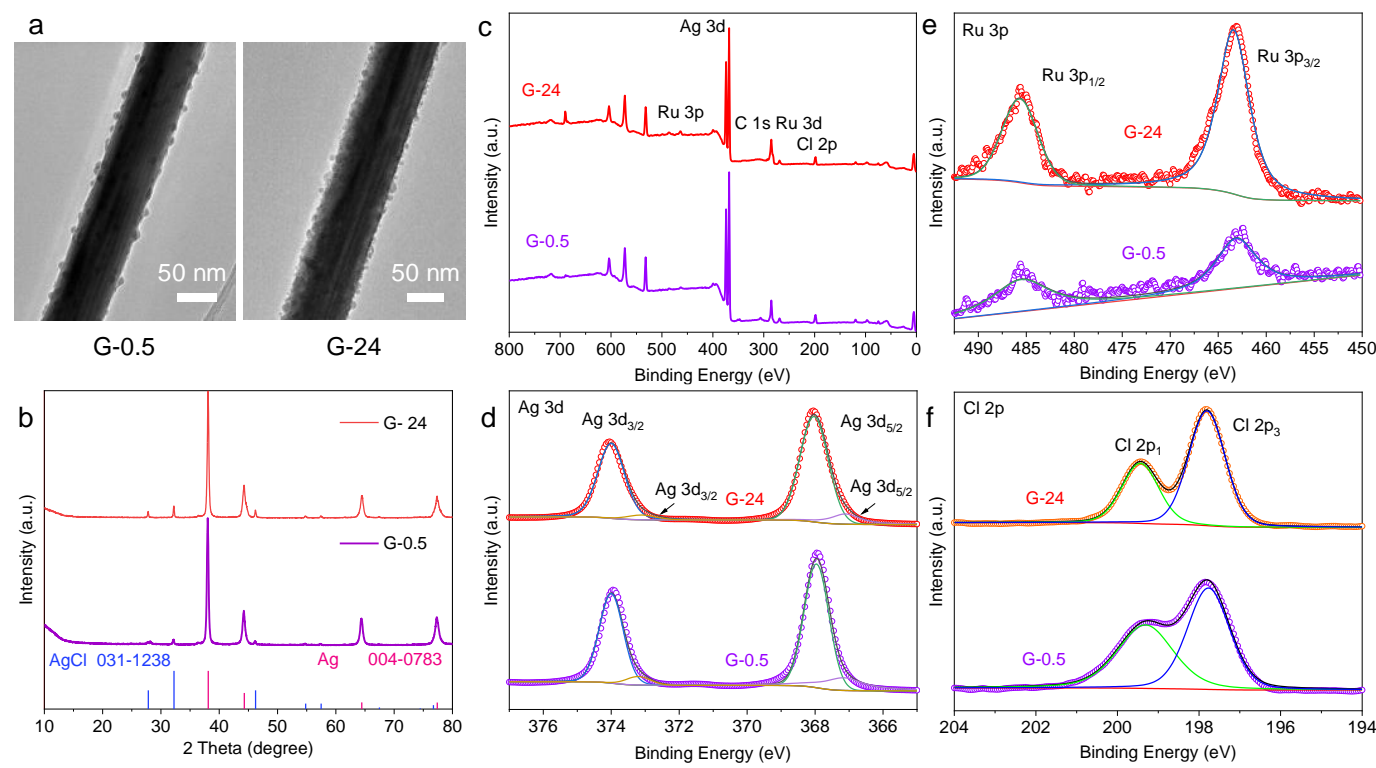

Fig. S2 (a) TEM image of G-0.5 and G-24. (b) XRD patterns of GRR samples. (c)

XPS full-scan spectrum of G-0.5 and G-24. High-resolution spectra of (d) Ag 3d, (e)

$\mathrm{Ru} 3 \mathrm{p}$, and (f) $\mathrm{Cl} 2 \mathrm{p}$ of G-0.5 and G-24. 

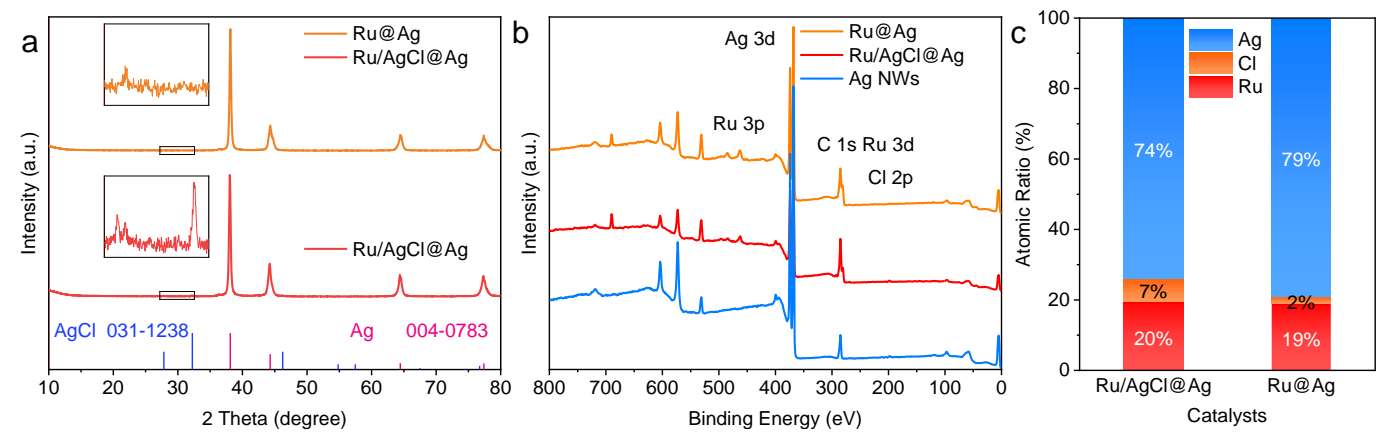

Fig. S3 (a) XRD patterns of Ru/AgCl@Ag and Ru@Ag. (b) XPS full-scan spectrum of Ru/AgCl@Ag, Ru@Ag, Ag NWs. (c) Component ratio variation of Ru/AgCl@Ag and Ru@Agby XPS. 

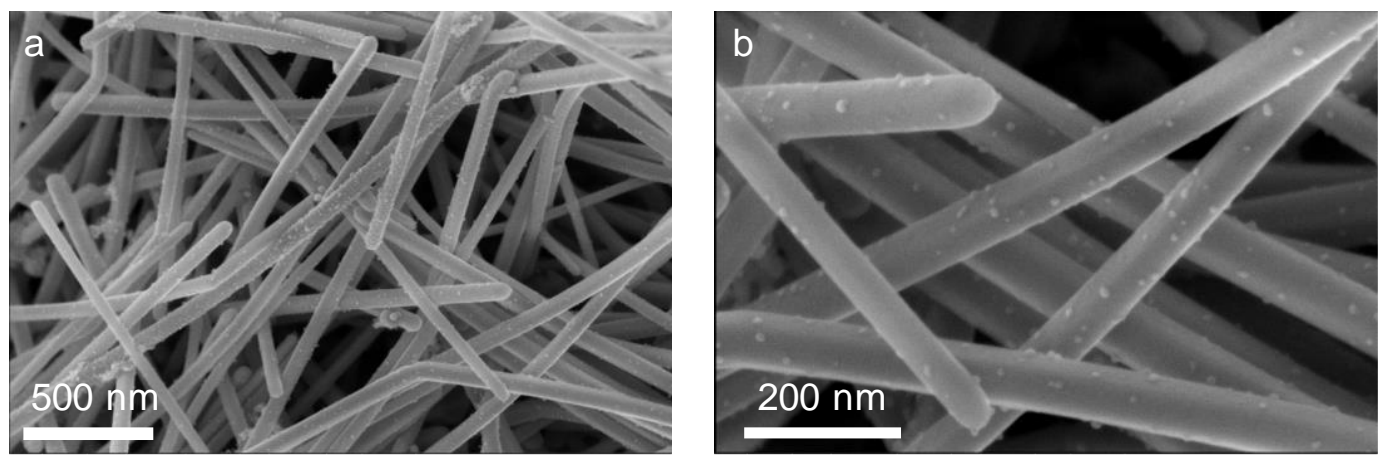

Fig. S4 SEM images of Ru/AgCl@ Ag. 


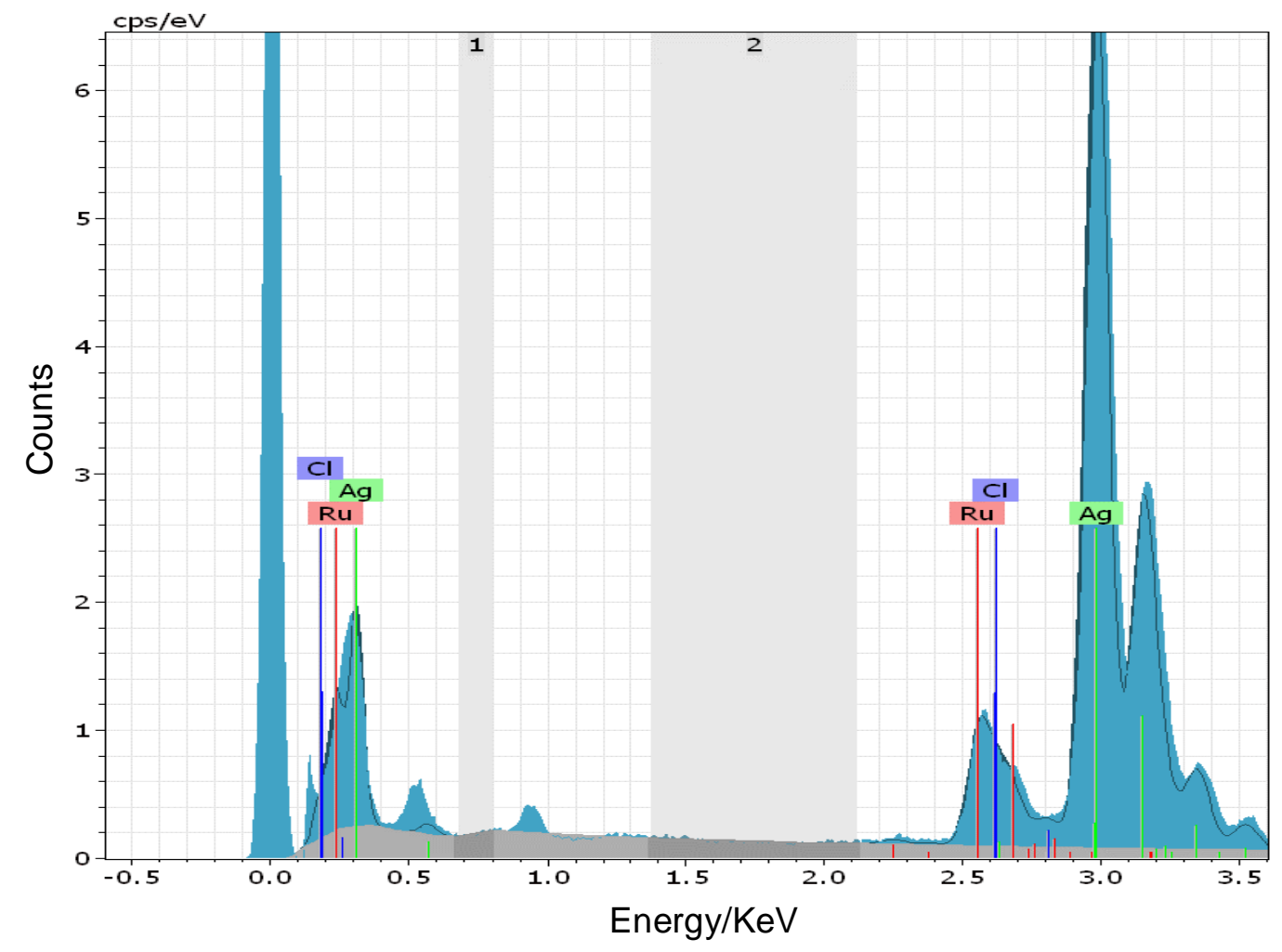

Fig. S5 EDS spectrum of Ru/AgCl@ Ag NWs. 


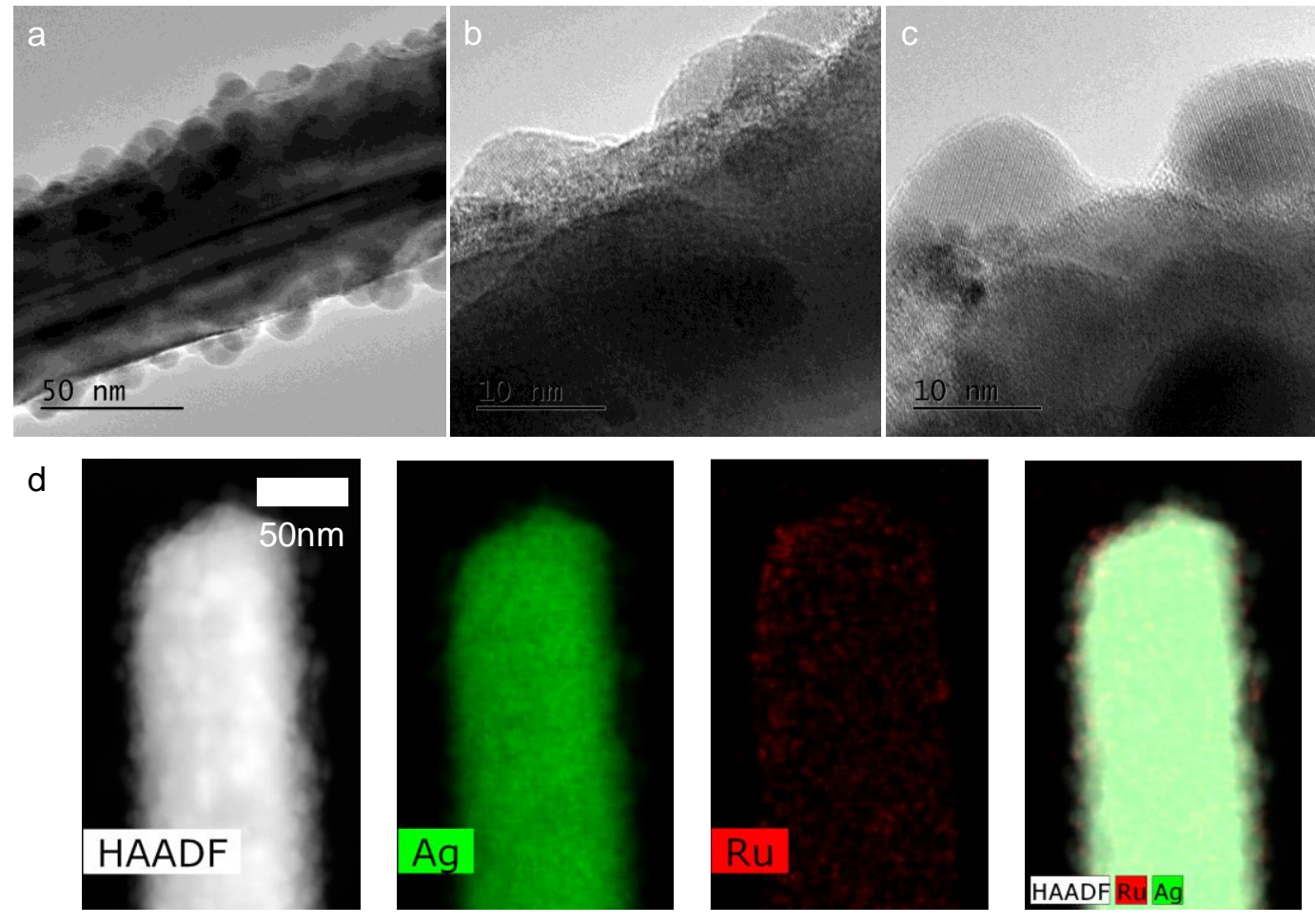

Fig. S6 TEM images (a), HRTEM images (b-c), HAADF and EDX element mapping images (d) of Ru @ Ag. 


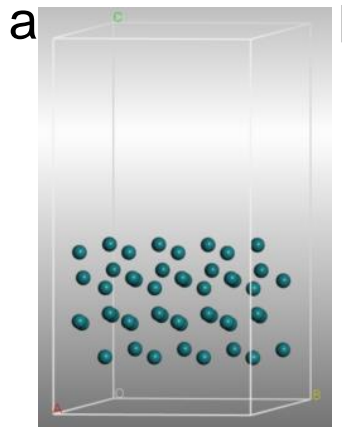

$\mathrm{Ru}(101)$

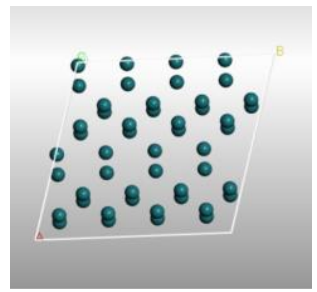

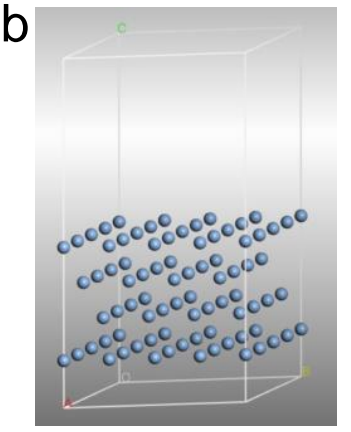

$\operatorname{Ag}(111)$

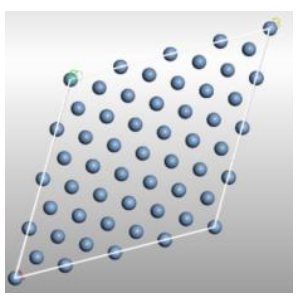

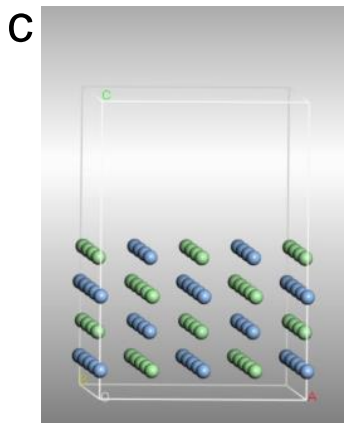

$\mathrm{AgCl}(110)$

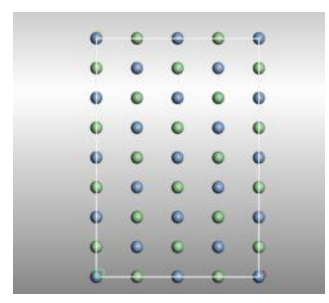

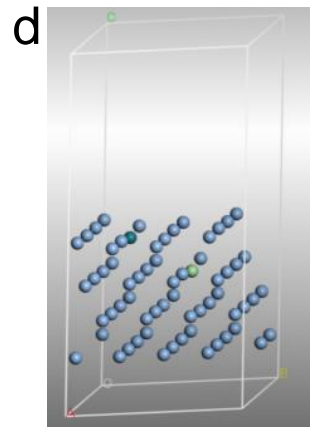

$\mathrm{Ru}-\mathrm{Cl}-\mathrm{Ag}(111)$

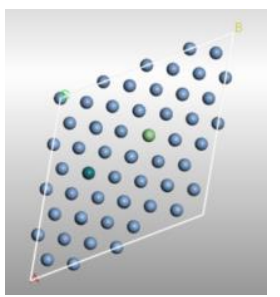

Fig. S7 Models for the theoretical simulation of free energy of adsorption of water molecules and $\mathrm{H}$ adsorption on the surface of different catalysts. The up panels show the side view of models, while the down panels show the corresponding top view of models. 


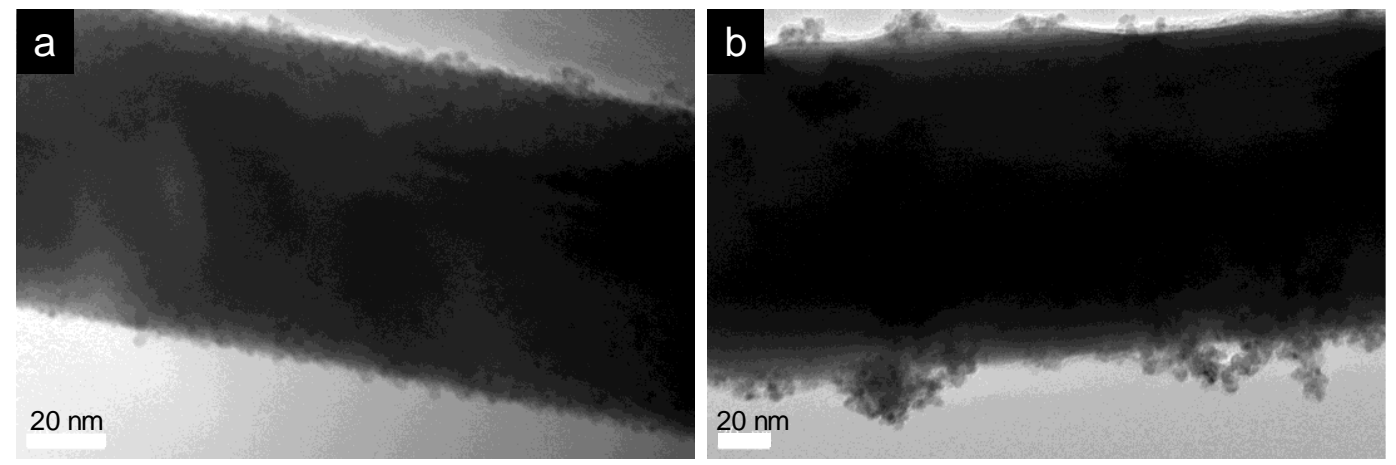

Fig. S8 TEM image of $\mathrm{Ru} / \mathrm{AgCl} @ \mathrm{Ag}-20 \%$ and $\mathrm{Ru} / \mathrm{AgCl} @ \mathrm{Ag}-30 \%$. 

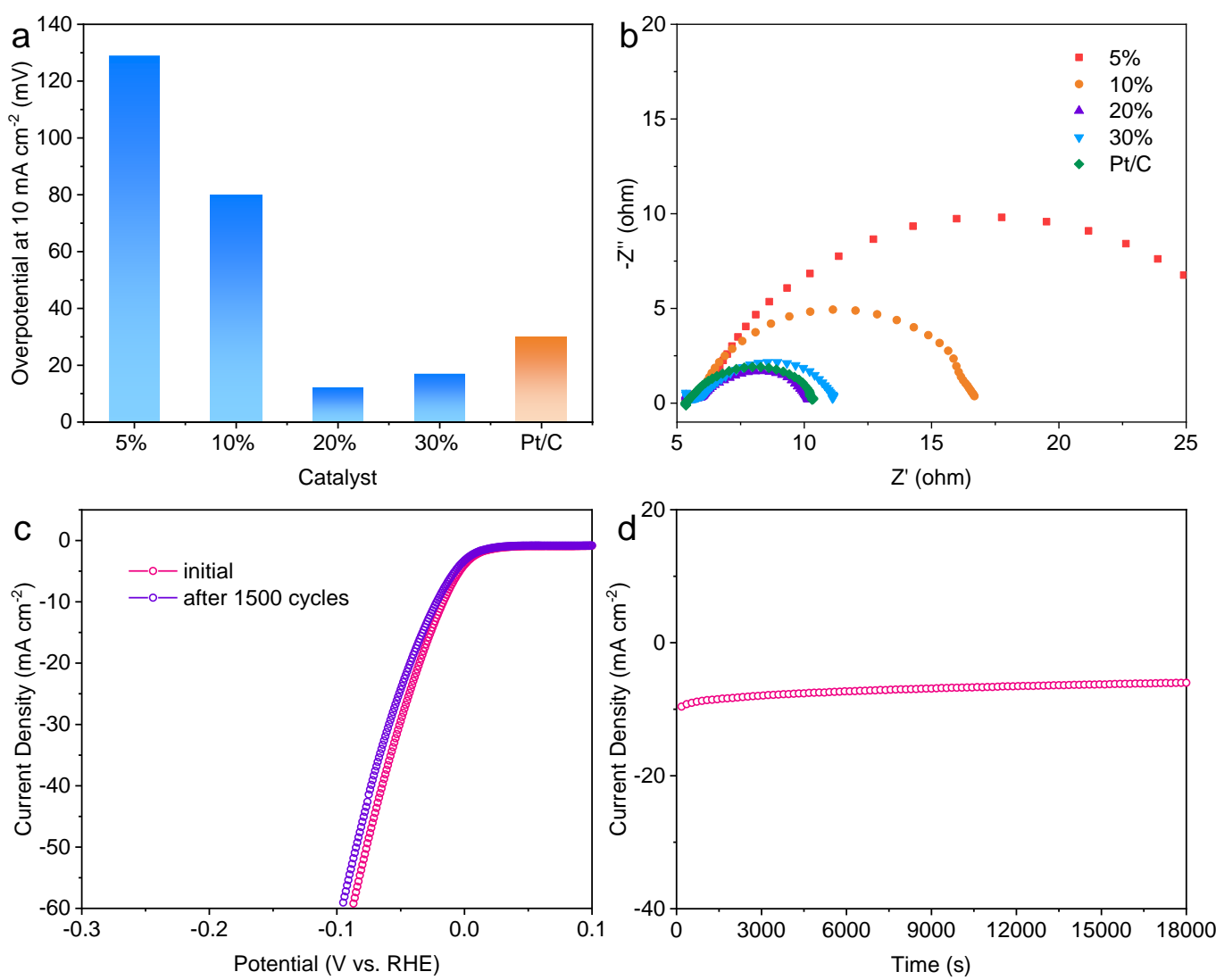

Fig. S9 (a) Overpotentials at $10 \mathrm{~mA} \mathrm{~cm}^{-2}$ and (b) EIS of $\mathrm{Ru} / \mathrm{AgCl} @ \mathrm{Ag}-\mathrm{X} \%$ and Pt/C.

Durability test of Ru/AgCl@ Ag-20\%. (C) Polarization curves are recorded before and after 1500 potential cycles in $1 \mathrm{M} \mathrm{KOH}$ solution from 0.13 to $-0.17 \mathrm{~V}$ Vs. RHE. (d) Time-dependent current density curve of $\mathrm{Ru} / \mathrm{AgCl} @ \mathrm{Ag}-20 \%$ under static overpotential of $30 \mathrm{mV}$ for $18000 \mathrm{~s}$. 

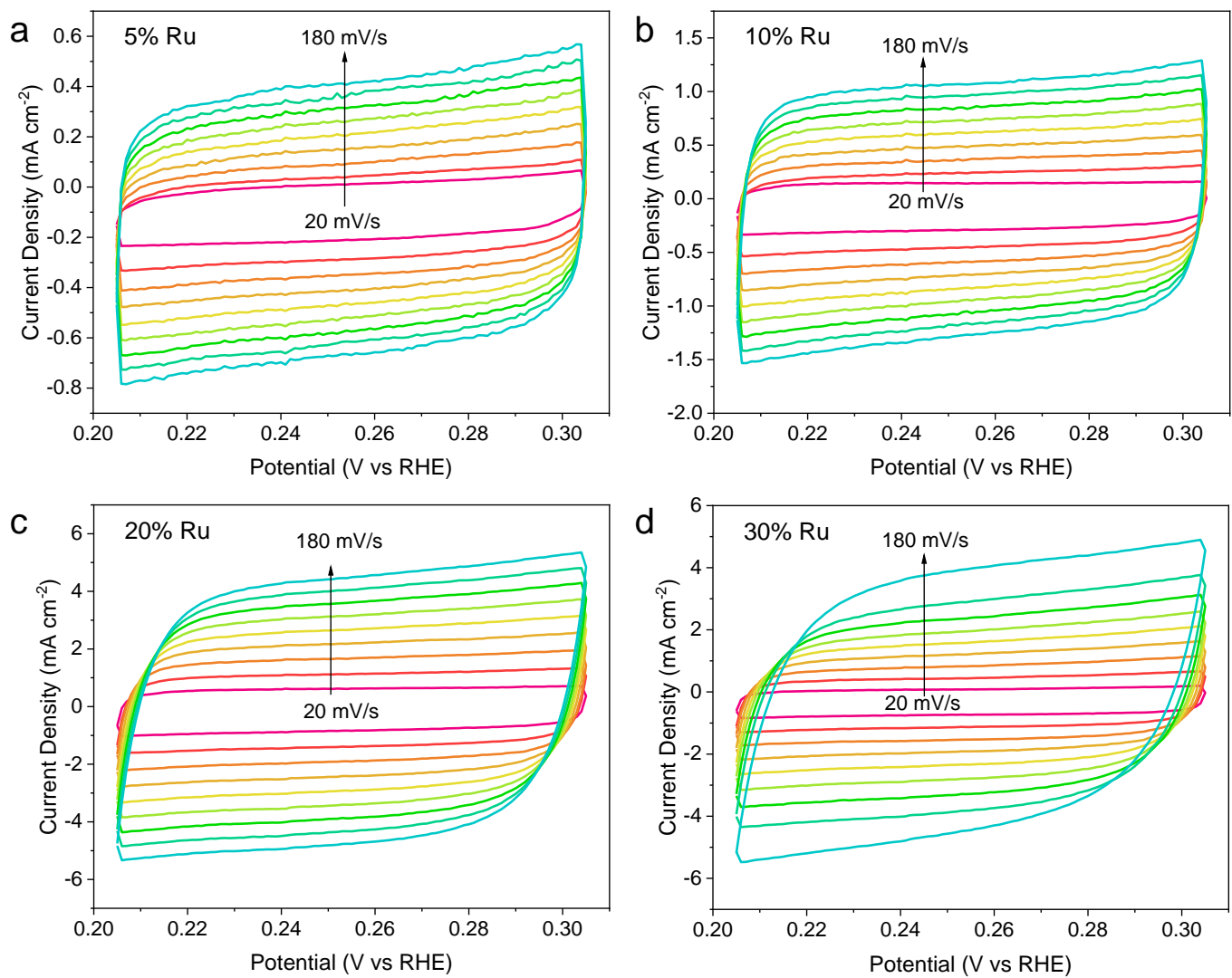

Fig. S10 CVs for Ru/AgCl@ Ag-x\%, (a) 5\%, (b) 10\%, (c) 20\%, and (d) 30\%. 

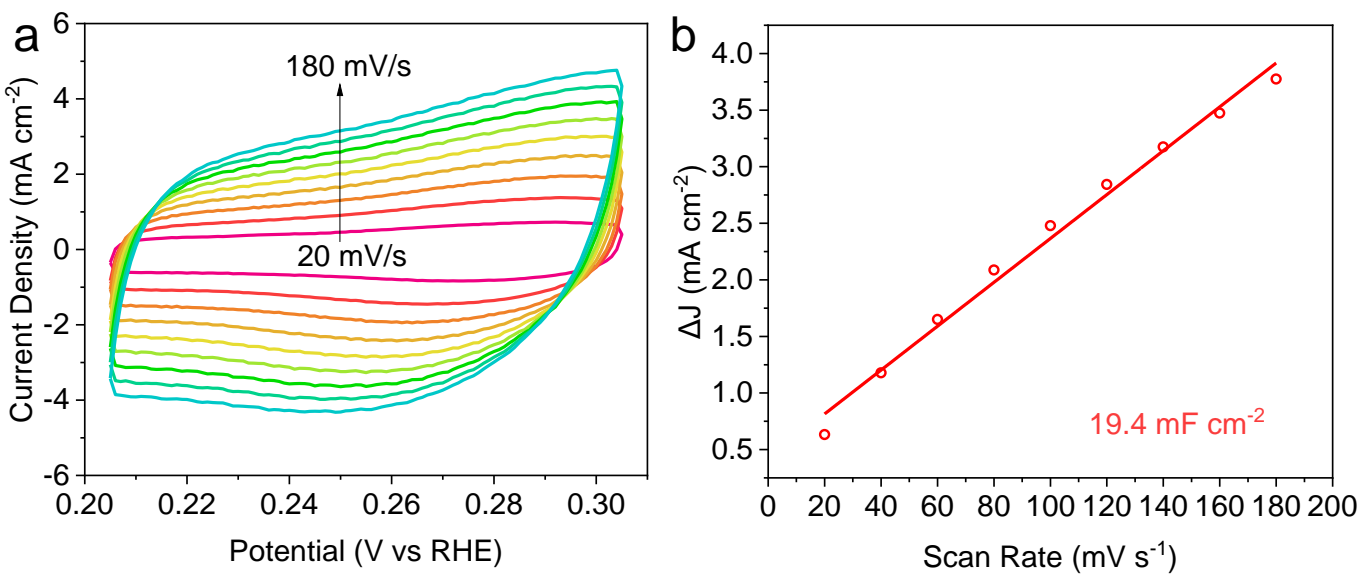

Fig. S11 (a) CV for Pt/C, and (b) the capacitive current density as a function of scan rate $(\Delta \mathrm{j}=\mathrm{ja}-\mathrm{jc})$. 
Table S1 Price average dollars per troy ounce.

\begin{tabular}{|c|c|c|c|c|c|}
\hline & $\mathbf{2 0 1 3}$ & $\mathbf{2 0 1 4}$ & $\mathbf{2 0 1 5}$ & $\mathbf{2 0 1 6}$ & $\mathbf{2 0 1 7}$ \\
\hline Silver & 23.89 & 19.09 & 15.72 & 17.20 & 17.20 \\
\hline Ruthenium & 75.63 & 65.13 & 47.63 & 42.00 & 61.00 \\
\hline Platinum & 1489.57 & 1387.89 & 1056.09 & 989.52 & 960.00 \\
\hline
\end{tabular}

Reference:

Ober, J. A. Mineral commodity summaries 2018; US Geological Survey: 2018. 
Table S2 Chemical state of O in Ru/AgCl@Ag and Ru@Ag under UHV and water pressure.

\begin{tabular}{|c|c|c|c|c|}
\hline Sample & Pressure & $\begin{array}{c}\text { Chemical } \\
\text { state }\end{array}$ & $\begin{array}{c}\text { Binding Energy } \\
(\mathrm{eV})\end{array}$ & $\begin{array}{c}\text { Atomic } \\
\text { percentage }(\%)\end{array}$ \\
\hline \multirow{9}{*}{ Ru/AgCl@Ag } & \multirow{4}{*}{ UHV } & $\mathrm{O}^{2-}$ bulk & 529.2 & 3.9 \\
\hline & & Ads. ${ }^{*} \mathrm{OH}$ & 530.3 & 35.0 \\
\hline & & Surface $\mathrm{O}^{2-}$ & 531.7 & 57.8 \\
\hline & & Ads. $\mathrm{H}_{2} \mathrm{O}$ & 533.3 & 3.3 \\
\hline & \multirow{5}{*}{$\begin{array}{l}0.12 \\
\text { mbar } \\
\mathrm{H}_{2} \mathrm{O}\end{array}$} & $\mathrm{O}^{2-}$ bulk & 529.3 & 2.6 \\
\hline & & Ads. ${ }^{*} \mathrm{OH}$ & 530.5 & 46.3 \\
\hline & & Surface $\mathrm{O}^{2-}$ & 531.7 & 43.2 \\
\hline & & Ads. $\mathrm{H}_{2} \mathrm{O}$ & 533.3 & 5.6 \\
\hline & & $\mathrm{H}_{2} \mathrm{O}$ gas & 535.4 & 2.3 \\
\hline \multirow{9}{*}{ Ru@Ag } & \multirow{4}{*}{ UHV } & $\mathrm{O}^{2-}$ bulk & 529.1 & 2.2 \\
\hline & & Ads. $* \mathrm{OH}$ & 530.4 & 45.4 \\
\hline & & Surface $\mathrm{O}^{2-}$ & 531.7 & 49.7 \\
\hline & & Ads. $\mathrm{H}_{2} \mathrm{O}$ & 533.2 & 2.7 \\
\hline & \multirow{5}{*}{$\begin{array}{l}0.12 \\
\text { mbar } \\
\mathrm{H}_{2} \mathrm{O}\end{array}$} & $\mathrm{O}^{2-}$ bulk & 529.3 & 3.5 \\
\hline & & Ads. $* \mathrm{OH}$ & 530.4 & 44.3 \\
\hline & & Surface $\mathrm{O}^{2-}$ & 531.8 & 48.29 \\
\hline & & Ads. $\mathrm{H}_{2} \mathrm{O}$ & 533.3 & 2.0 \\
\hline & & $\mathrm{H}_{2} \mathrm{O}$ gas & 535.4 & 1.87 \\
\hline
\end{tabular}


Table S3 Comparison of HER performance with results in recent literatures.

\begin{tabular}{|c|c|c|c|c|}
\hline Catalyst & $\begin{array}{l}\text { Overpotential } \\
\text { @10 mA cm- } \\
{ }^{2}(\mathrm{mV})\end{array}$ & $\begin{array}{c}\text { Electrolyte } \\
\text { solution }\end{array}$ & $\begin{array}{l}\text { Tafel slope } \\
\left(\mathbf{m V} \operatorname{dec}^{-1}\right)\end{array}$ & Reference \\
\hline Ru/AgCl@Ag & 12 & 1.0 М КОН & 38 & This work \\
\hline Ru@NC & 26 & $1.0 \mathrm{M} \mathrm{KOH}$ & 36 & $\begin{array}{l}\text { Angew. Chem. } \\
\text { Int.Ed. } 2018 \text {, } \\
\text { 57(20): } 5848- \\
5852 .\end{array}$ \\
\hline \multirow{2}{*}{$\mathrm{Ru} @ \mathrm{C}_{2} \mathrm{~N}$} & 22 & $0.5 \mathrm{M} \mathrm{H}_{2} \mathrm{SO}_{4}$ & 30 & \multirow{2}{*}{$\begin{array}{l}\text { Nat. Nanotech. } \\
\text { 2017, 12, } 441\end{array}$} \\
\hline & 17 & $1.0 \mathrm{M} \mathrm{KOH}$ & 38 & \\
\hline $\mathrm{Ru} / \mathrm{C}_{3} \mathrm{~N}_{4} / \mathrm{C}$ & 79 & $0.1 \mathrm{M} \mathrm{KOH}$ & & $\begin{array}{c}\text { J. Am. } \\
\text { Chem.Soc. } \\
\text { 2016, } \\
\text { 138,16174 }\end{array}$ \\
\hline $\begin{array}{l}\text { Co-substituted } \\
\qquad \mathrm{Ru}\end{array}$ & 13 & $1.0 \mathrm{M} \mathrm{KOH}$ & 29 & $\begin{array}{l}\text { Nat.commun.20 } \\
\text { 18,9(1): } 4958 .\end{array}$ \\
\hline \multirow{2}{*}{$\mathrm{Ru} @ \mathrm{GnP}$} & 13 & $0.5 \mathrm{M} \mathrm{H}_{2} \mathrm{SO}_{4}$ & 30 & \multirow{2}{*}{$\begin{array}{c}\text { Adv. Mater. } \\
\text { 2018: } 1803676 .\end{array}$} \\
\hline & 22 & $1.0 \mathrm{M} \mathrm{KOH}$ & 28 & \\
\hline $\mathrm{Ru} @ \mathrm{CN}$ & 32 & $1.0 \mathrm{M} \mathrm{KOH}$ & 53 & $\begin{array}{c}\text { Energy Environ. } \\
\text { Sci. } 2018, \\
\text { 11(4): } 800-806 .\end{array}$ \\
\hline $\mathrm{Ru} / \mathrm{CN}$ & 14 & $1.0 \mathrm{M} \mathrm{KOH}$ & 30 & $\begin{array}{c}\text { ACS } \\
\text { Sustainable } \\
\text { Chemistry \& } \\
\text { Engineering.201 } \\
\text { 8, 6(9): } 11487- \\
11492 .\end{array}$ \\
\hline
\end{tabular}




\begin{tabular}{|c|c|c|c|c|}
\hline $\mathrm{Ru}^{0} / \mathrm{CeO}_{2}$ & 47 & $0.5 \mathrm{M} \mathrm{H}_{2} \mathrm{SO}_{4}$ & 41 & $\begin{array}{c}\text { ACS Appl } \\
\text { Mater } \\
\text { Interfaces.2018, } \\
\text { 10(7): 6299- } \\
6308 .\end{array}$ \\
\hline $\mathrm{RuP}_{2}$ & 33 & $1.0 \mathrm{M} \mathrm{KOH}$ & 56 & $\begin{array}{c}\text { Nanoscale. } \\
\text { 2018, 10(29): } \\
\text { 13930-13935. }\end{array}$ \\
\hline $\mathrm{Ru} / \mathrm{C}$ & 14 & $1.0 \mathrm{M} \mathrm{KOH}$ & 32.5 & $\begin{array}{c}\text { Journal of } \\
\text { Materials } \\
\text { Chemistry } \\
\text { A.2018, 6(29): } \\
\text { 14380-14386. }\end{array}$ \\
\hline $\mathrm{Ru} / \mathrm{MoS}_{2} / \mathrm{CP}$ & 13 & $1.0 \mathrm{M} \mathrm{KOH}$ & 60 & $\begin{array}{c}\text { Nanoscale.2017 } \\
\begin{array}{c}9(43): 16616- \\
16621 .\end{array}\end{array}$ \\
\hline \multirow{2}{*}{ Ru-HPC } & & $1.0 \mathrm{M} \mathrm{KOH}$ & 33.9 & \multirow{2}{*}{$\begin{array}{l}\text { Nano Energy. } \\
\text { 2019,58, 1-10. }\end{array}$} \\
\hline & 61.6 & $0.5 \mathrm{M} \mathrm{H}_{2} \mathrm{SO}_{4}$ & 66.8 & \\
\hline $\begin{array}{c}\text { Ru-NC-700 } \\
\text { nanowires }\end{array}$ & 12 & $1.0 \mathrm{M} \mathrm{KOH}$ & & $\begin{array}{c}\text { Nat Commun. } \\
\text { 2019,10 (1), } \\
631 .\end{array}$ \\
\hline
\end{tabular}

